\title{
Norm Transmission in Peace- and Statebuilding: Lessons from Democracy Promotion in Sudan and Lebanon
}

\author{
Marie-Joëlle Zahar
}

\begin{abstract}
This article examines the transmission and reception of democratic norms in the context of liberal peace interventions. It identifies two reasons for the failure to promote democracy: the strategies favored by liberal peace actors and the agency of local elites. Drawing on field research in Lebanon and Sudan, the article argues that liberal peace projects systematically provide opportunities for local elites to overcome the apparent asymmetry of power between them and liberal peace actors. It identifies two strategies of resistance to the promotion of democracy—disengagement and recuperation-and suggests that, of the two, disengagement is more likely to produce a relapse into violence. KEYWORDS: democracy promotion, hybrid peace governance, norm transmission and recuperation, Sudan, Lebanon.
\end{abstract}

FROM A SECURITY DILEMMA PERSPECTIVE, CIVIL WAR IS THE VIOLENT INTERACTION of groups that feel threatened and, in the absence of the state, fight for their survival. ${ }^{1}$ From a social contract perspective, civil war results from a breach in the social contract with a captured state fighting one or more insurgent groups in society. ${ }^{2}$ Regardless of one's favored account, democracy promotion is an important part of the toolkit of post-civil war peace- and statebuilding interventions. Democratization builds peace vertically; it strengthens the social contract and builds states that are bound by the rule of law and autonomous from sectional interests. Democratization also builds peace horizontally by providing mechanisms of power- and wealth-sharing allowing warring factions to manage their conflicts peacefully.

In this article, I examine the transmission and reception of democratic norms in the context of peace- and statebuilding interventions in Lebanon and Sudan. Located in highly geostrategic regions, these two fragile states have hosted US-designated foreign terrorist organizations. Sudan and Lebanon are postconflict environments in the limited sense that interventions followed the signing of a formal peace agreement. But they are not postwar environments. ${ }^{3}$ War broke out in Darfur following the signing of the Comprehensive Peace Agreement (CPA) between the government of Sudan and the Sudan People's Liberation Movement (SPLM). Since the July 2011 independence of South Sudan, violence has convulsed the border with the old Sudan. Although 
Lebanon's civil war ended with the signing of the Ta'if Agreement in 1990, in 2006 armed confrontations opposed the Hezbollah and Israel and, in May 2008 , intra-Lebanese violence rekindled fears of civil war. In these contexts of hybrid peace governance, Western actors' incentives to bring about democracy should be high, given perceived linkages between domestic conditions and regional and international security challenges.

Why, in spite of strong incentives and relatively sustained efforts, have liberal peacebuilders met with only limited success in their efforts to promote democracy in Lebanon and Sudan? What, if any, impact do these outcomes have on the stability of peace? In this article, I identify two reasons for the failure to promote democracy: the approach to democracy promotion favored by outsiders and the agency of insiders as they fight against or adapt democracy promotion to their own ends. Drawing on empirical evidence I argue that, under a specific set of conditions, local actors can either sidestep the liberal peace project or divert symbolic and financial resources intended to buttress democracy promotion in ways that undermine the project.

\section{Democracy Promotion and Transitions from War to Peace}

Since the early 1990s, countries coming out of civil wars have been the theater of liberal peacebuilding and postconflict reconstruction missions where "the presence of foreign military troops [is] used by outsiders to control political outcomes."4 Their ultimate objective is "to create stable, tolerant, more liberal and democratic regimes out of the wreckage of war-torn societies."

Liberal peacebuilders consider democracy promotion central to the sustainability of peace. In the short term, democracy provides mechanisms to overcome the deep mistrust between parties and minimize the risk of spoiling. ${ }^{6}$ It promises that parties will be meaningfully represented in the political system and that they will contest elections but will not have to fear the consequences of defeat at the polls. Some sort of democratic institutional setup, often involving power sharing, is therefore considered important to address the short-term challenges of war-to-peace transitions. ${ }^{7}$ In the longer term, sustainable peace requires the institutionalization of mechanisms of nonviolent conflict management. To prevent a return to war, political and socioeconomic grievances that mobilize fighters must also be addressed ${ }^{8}$ as undemocratic practices and rules for resource allocation, such as corruption and patronage, exacerbate grievances and contribute to the emergence of violence. ${ }^{9}$

In postconflict environments, democracy promotion refers to the range of programs and policies intended to transform state-society and intergroup relations. Donors conceive of peacebuilding and postconflict reconstruction aid not simply as a response to immediate needs, but as a tool that can be used for 
conflict prevention, to promote peaceful methods of conflict resolution, to establish and foster interrelationships between former enemies, and to disseminate a culture characterized by the rule of law and the respect for basic rights and liberties.

Analysts identify two approaches to democracy promotion. ${ }^{10}$ A political approach focuses on procedural aspects of democracy such as the conduct of free and fair elections and the respect of political liberties. It seeks to empower democrats against nondemocrats through support and targeted interventions at critical junctures. Examples include election-monitoring missions such as the European Union's Electoral Observation Mission in the 2005 Lebanese parliamentary election that followed the assassination of former prime minister Rafik Hariri, the Cedar Revolution, and Syria's withdrawal from Lebanon. In Sudan, the April 2010 elections provided the opportunity for an impressive electoral monitoring deployment. Indicators of democracy promotion can thus be measured in terms of the regular holding of free and fair elections and respect for civil liberties using long-standing indexes and measures such as Freedom House's scores.

The developmental approach takes a longer view of democracy as a slow iterative process of interconnected political, economic, social, cultural, and attitudinal changes. "It favors democracy aid that pursues incremental, longterm change in a wide range of political and socioeconomic sectors, frequently emphasizing governance and the building of a well-functioning state."11 This translates into a focus on three key programming sectors: governance, security, and rule of law.

Support for governance activities has stemmed from the proposition that accountable and capable state institutions are a prerequisite for economic development. The realization that law and order is a priority in conflict management has contributed to the growth of security sector reform and rule of law programs. ${ }^{12}$

Measuring this more substantive understanding of democracy promotion is not easy. The developmental approach to democracy promotion overlaps with broader development aid. Its success is a function of its ultimate ability to enhance state efficiency, accountability, and transparency. Efficiency can be evaluated by a state's ability to tax and provide basic services; reform of the key sectors of security and justice can be used as proxies to assess accountability. Indexes such as Transparency International's measures of corruption capture some of the dimensions of this developmental approach to democracy. Nevertheless, accountability and efficiency require fine-grained substantive and qualitative assessments of the kind that are difficult to generalize and systematize. 


\section{Norms and Bargaining in Peace Processes}

The liberal peace has come under fire from several quarters. Some question its ability to achieve stability and deal with "devious incentives." 13 Others fault it for creating weak states by prioritizing liberalization over institutionalization. ${ }^{14}$ Still others bemoan its inability to build local ownership and pass the baton to local actors. ${ }^{15} \mathrm{~A}$ different perspective argues that liberal peace interventions are bound to produce hybrid outcomes. "International and domestic actors enter into a bargaining relationship whereby each attempts to promote its own values, norms and practices." 16 The resulting hybrid peace governance allows for the coexistence of liberal and illiberal norms, institutions, and actors in a no-war-no-peace context. Recent analyses stress the near inevitability of hybridity. For some, this stems from the variety of interests and agendas at play. ${ }^{17}$ For others, it is the natural outcome when path dependence, timing, and sequencing contribute to defining the realm of the possible in terms of the quality of postconflict governance. ${ }^{18}$ Others argue that hybridity results from the deployment of incentives and disincentives by international actors and the limits of these strategies in a context where limited understandings of the context of intervention and the multiplication of policy objectives are likely to result in strategy gridlocks. ${ }^{19}$

These approaches contrast sharply with descriptions of the liberal peace as a space of exception where little if any bargaining is possible. ${ }^{20}$ Several authors underline the highly asymmetrical nature of power in these contexts. Liberal peacebuilders can display substantial military might. In Kosovo, NATO mustered 50,000 troops from thirty-two member countries to deter spoilers. ${ }^{21}$ Outsiders can also have the upper hand in decisionmaking when local institutions of governance are destroyed or local actors are unwilling to cooperate. In Bosnia and Herzegovina, the international community endowed its high commissioners with such extensive powers that they were compared with "Viceroy[s] of India." 22 International actors also brandish the authority of the pocketbook; democratic conditionality has been a staple of liberal peace strategies. ${ }^{23}$ Perhaps more important, however, is the reallocation of symbolic resources: the promotion of Western norms and values that accompanies implicit and explicit critiques of local societies and the fragmentation of legitimacy between expatriates who invoke the moral authority of the international community and the technocratic authority of their personal efficacy and local elites torn between the competing legitimacies of collaboration and resistance.

Although an important reminder of differences between highly asymmetric and standard bargaining interactions, this literature fails to acknowledge the full range of options available to locals in the expression of their agency. It does not pay sufficient attention to their creativity, capacity, and resilience and is inadequately equipped to identify "weapons of the weak." 24 While power and resource asymmetries are an undeniable reality, an abundant literature on resistance to colonial rule draws on the notion of weapons of the weak 
to interrogate the repertoire of actions available to the less powerful. ${ }^{25}$ The massive arrival of international administrative personnel invariably provokes new social dynamics whose particular articulations require closer examination. Relations between locals and internationals introduce new resources and strategies into existing social, economic, and political games. In this new context, local elites can gain access to international organizations and develop mediation functions or collaborations in order to avail themselves of the material and symbolic resources made available by the international community. In the economic sphere, international actors representing new private and public sources of capital but requiring local agents provoke a reshuffling of the employment market as different skills acquire new (at least short-term) strategic value. In trying to adapt to the massive intrusion of international actors, local actors might not always have equivalent military might or financial resources; ${ }^{26}$ however, they possess the upper hand in understanding and navigating the local context. This provides them with a margin for maneuver to either resist more effectively, ignore and bypass the liberal peacebuilding initiatives, or adapt them to their specific ends and objectives.

\section{Socializing Locals to Democracy: \\ Norm Transmission and Reception in Sudan and Lebanon}

In Sudan and Lebanon, foreign donors have privileged political democracy promotion over the systematic engagement with and reform of state institutions in a way that privileges efficiency, accountability, and transparency. This particular mode of democracy promotion impacted local socialization into democratic norms and the ability of local leaders to position themselves vis-àvis the powerful apparatus deployed by the international community.

\section{Transmitting Democracy in Spurts and Starts}

Although foreign aid increasingly overlaps and converges with democracy promotion, liberal peace actors continue to place-at least outwardly-more emphasis on discrete events and critical junctures. ${ }^{27}$ Foreign donors mobilize in support of discrete benchmarks, the implementation of which is arguably central to maintaining horizontal peacebuilding and preventing relapse into violence. In Lebanon, Western donors became increasingly active following the assassination of Hariri. However, involvement peaked around three key events: the 2005 and 2009 elections and the summer 2006 Israel-Hezbollah war. And while democracy promotion efforts in Sudan followed the 2005 signing of the CPA, a spike was clearly noted in 2009 in anticipation of the 2010 election and 2011 referendum on the independence of South Sudan.

Mandated by the CPA, the April 2010 elections were central to the implementation of the agreement and to the process leading up to the 2011 referendum. Liberal peace actors mobilized in support of their peaceful and orderly 
conduct. The European Union deployed its largest election observation mission ever with 130 observers from twenty-two countries. The UN basket fund for elections amounted to over $\$ 84$ million. ${ }^{28}$ The election and referendum support budget of the US Agency for International Development (USAID) amounted to $\$ 95$ million. Similarly, liberal peace actors mobilized in support of parliamentary and municipal elections in Lebanon. Ahead of the 2009 parliamentary elections, for example, USAID worked through the Consortium for Elections and Political Processes Strengthening (CEPPS) to train domestic election observers and officials and provide technical assistance to the Ministry of Interior and Municipalities to facilitate citizen access to voting and registration.

This is not to say that liberal peace actors are not interested in vertical peacebuilding. However, programs to improve state efficiency, accountability, and transparency are technocratic and, therefore, less visible. During the CPA period, Canada provided technical support to the Fiscal and Financial Allocation and Monitoring Commission (FFAMC) to assist civil servants in developing and implementing a fair allocation formula for the distribution of resources in Sudan. In Lebanon, since early 2010, USAID and the US Department of Treasury have provided a technical adviser to support the director general of the Ministry of Finance to develop effective procedures for transparency and oversight as well as strengthen internal controls in financial reporting.

Not only do political democracy promotion efforts enjoy higher visibility, they sometimes appear to enjoy a proportionally high percentage of resources when measured against the level of developmental need and given the role of socioeconomic grievances in the initial mobilization of fighters. For example, USAID's electoral assistance budget comprised a full 2 percent of the $\$ 6$ billion envelope that the agency has disbursed in Sudan since 2005. While this might not strike the casual observer as a large percentage, in spite of its oil wealth, Sudan ranks 154th on the 2010 Human Development Index. To provide a better vantage point, the cost of linking the main towns of South Sudan to its capital, Juba, is estimated at $\$ 7$ billion. ${ }^{29}$

However, as stated by a senior human rights officer at the UN Mission in Sudan (UNMIS), the push for peace is often much stronger than that for democracy. ${ }^{30}$ As a result, there is little interest in the quality and content of various benchmarks in the implementation of peace processes. ${ }^{31}$ In the words of a donor official, UNMIS "staked its credibility on holding the April 2010 elections." 32 It thus became more important to hold elections on time than to ensure their quality. While liberal peace actors certified the April 2010 election, many privately (and some publicly) expressed concerns about the democratic quality of the exercise. When the imperatives of peace and democracy collide, as they often do, liberal peace actors privilege stability. In the host so- 
ciety, such behavior induces suspicions about the genuineness of their interest in democratic transformation.

That locals perceive democracy promotion as a selective enterprise is further deepened by the fact that liberal peace actors sometimes attempt to steer events in directions congruent with their interests and that increased interest in and support for a country can be juxtaposed with conditionality or outward aid denial intended to weaken specific domestic factions. Following the 2006 Israel-Hezbollah war, Western donors gave to an Emergency Flash Appeal, but several "exerted pressures on UN agencies and NGOs [nongovernmental organizations] not to meet or provide assistance to Hizbollah."33 A few days before the parliamentary election of 2009, the US State Department suggested it might suspend its military aid to the country if Hezbollah was victorious at the polls. In Sudan, "the US government strongly backed the CPA negotiations, indicating that once the deal had been signed, the US would move rapidly towards normalizing relations with Sudan, including lifting long-standing bilateral sanctions, providing development assistance, and probably also bringing a US major oil company to Sudan and facilitating debt relief."34 Public outcry over events in Darfur prevented the United States from making good on its promises, which left the government of Sudan and its supporters to feel betrayed. During the transitional period, democracy promotion has often meant siding with President Omar al-Bashir's opponents, at the risk of overlooking their fledgling democratic credentials. While criticisms of al-Bashir's behavior were the norm, there was much more muted public expression of dissatisfaction with the SPLM leadership's undemocratic practices. ${ }^{35}$

In summary, three factors contribute to perceptions that liberal peace actors are selective in their transmission of democratic norms. First is the prominence of political over developmental democracy promotion. Second is the tendency, at critical times, to privilege peace at the expense of democracy. Third is the difficulty of transmitting democratic norms coherently while simultaneously trying to undercut specific actors for broader security considerations.

\section{Selecting Local Partners}

How do local actors, particularly elites, position themselves in the bargaining relationship established by liberal peace actors as they attempt to socialize locals to democracy? Much depends on who these elites are. Local actors vary both in terms of their attitudes toward democracy and in terms of their ability to develop strategies congruent with their preferences. I first address the variety of local actors with whom liberal peace actors have to contend before turning to their strategies.

Fieldwork in Sudan and Lebanon raises concerns about the liberal peace actors' ability to select partners who will be both credible and representative. The first dilemma concerns the paradox whereby warring parties must be in- 
cluded in peace processes in order for peace to hold. Once in power, however, these actors often constrain democratic opponents from playing an effective role in postconflict governance. Analysts identify power sharing as an institutional formula likely to deepen this paradox. ${ }^{36}$ In Sudan, al-Bashir's National Congress Party was one of the two partners in the CPA. Highly restrictive laws, including the media and NGO laws, constrained democracy promotion in the country. Furthermore, liberal peace actors depended on the government's goodwill to operate in the country. Several interviewees confirmed that they sometimes exercised self-censorship to remain on the ground. In the words of one interviewee, "the UN can be threatened with expulsion by a bully government and its security forces. A former UNMIS person told me that the attitude was to keep one's head down to save good jobs and salaries." 37

The second dilemma concerns the choices that liberal peace actors face in selecting local partners. Should they privilege groups who speak their language and share their values but may not necessarily have local legitimacy, or should they work with representative societal actors in spite of potential linguistic and cultural barriers? In Lebanon, liberal peace actors have privileged civil society organizations manned by foreign-educated, French- or Englishspeaking youth. However, once their limited reach became evident, donors fell back on communal organizations whose rootedness in society equipped them better to carry out programs. Thus, many NGOs established to weaken the hold of sectarian elites on Lebanese society since 2005 have now become defunct. ${ }^{38}$ In Sudan, liberal peace actors relied heavily on diaspora communities. This was not only the case in the North where the regime had muffled civil society until 2005, but also in the South where human resources are a major challenge. In the words of an interviewee, "this has created an elite of national NGOs who are becoming a buffer [between the international community and the grassroots]. Civil society is becoming a business." 39 This is echoed by Samer Abdallah of the Lebanese NGO Nahwa al-Muwatiniyya who argues that relations with liberal peace actors professionalized Lebanese NGOs and squandered the volunteering spirit of members..$^{40}$

This problem is compounded by the overlap between local conflict dynamics and international security issues. For example, in Lebanon, the decision of Western governments to label Hezbollah a terrorist organization has limited the ability to interact with a group that garnered 88 percent of the Shi'ite vote and, in conjunction with its allies, 54 percent of the popular vote in the 2009 election. ${ }^{41}$ According to Roger Mac Ginty, "Personnel from one US-based international NGO noted how because of their USAID funding they were unable to deal with Hezbollah, even though Hezbollah were important gatekeepers to the community they wished to assist." 42

In summary, the transmission of democratic norms runs against hard choices in the selection of local partners. Like the strategies adopted by liberal peace actors, their choice of partners affects local perceptions of the democ- 
racy promotion agenda. Together, these two factors provide the context within which local elites develop their own strategies in response to the attempt by liberal peace actors to promote democracy.

\section{Weapons of the Weak}

How do local elites engage with efforts by their international counterparts to transmit democratic norms? To the casual observer of peace- and statebuilding efforts, the asymmetry between international and local resources may sometimes seem glaring. Particularly where liberal peace actors have displayed commitment and interest, they deploy significant financial, military, and human resources on the ground. This was arguably the case in Lebanon and Sudan after 2005. Following the summer 2006 war between Hezbollah and Israel, the UN Security Council agreed to strengthen the UN Interim Force in Lebanon bringing the total number of troops deployed to 15,000 , most of which, as against common practice, came from Western nations. In Sudan, the deployment of UNMIS and later on the African Union/United Nations hybrid operation in Darfur (UNAMID) involved a total of about 30,000 troops. Attempts were also made to weaken perceived local illiberal actors. Pressure was applied on Hezbollah in Lebanon through the Special Tribunal for Lebanon (STL) investigating the Hariri assassination. In Sudan, the International Criminal Court indicted al-Bashir and high-ranking members of the ruling National Congress Party (NCP) for genocide in Darfur. Both countries also received substantial monies in support of postconflict reconstruction.

Why then were some local elites who were opposed to the liberal peace project capable of resisting and what strategies did they use to this effect? The focus on actors opposed to the liberal peace project is not intended to suggest that there are no prodemocracy elites in either Sudan or Lebanon. However, to the extent that a bargaining relationship is established between local and international actors, one would expect the liberal peace actors to bring the might of their resources to bear on local opponents or competitors. By focusing on the local elites' ability to resist, I shed light on the terms and context of the bargaining relationship.

Liberal peace actors' choice of strategies and partners affects local perceptions of democracy promotion. They also provide a more or less constraining environment in which local elites develop their strategies. I suggested that the perceived selectiveness of liberal peace actors' democracy promotion efforts and their competing agendas provide local elites with an opportunity to capitalize on resulting popular suspicions. I also argued that the liberal peace actors' decision to interact with or counter local elites affects the stance of these elites. The more representative the local elites, the more likely it will be for their strategies to affect the nature of postconflict governance. In Sudan and Lebanon, local elites opposed to the liberal peace project have relied on two main strategies: disengagement from the liberal peace project and recu- 
peration of the democratic vocabulary to their own ends. The two strategies are not exclusive of one another. However, they potentially have different consequences for the nature of postconflict governance.

It is not uncommon in peace- and statebuilding settings to find two (or more) competing systems of authority on the same territory. Liberal peace actors and their local partners share authority and legitimacy with a parallel system of governance run by local elites opposed to the liberal peace project. In such instances, the population sees locals who partner with the international community as collaborators. Such is the situation in Lebanon's Shi'a strongholds in the southern suburbs of Beirut and in South Lebanon. Here, disengagement is facilitated by widely held popular perceptions that aid is politicized. Buttressed by the selectiveness of Western liberal peace efforts, including the US government's interdiction of contacts with Hezbollah and by UN Security Council Resolution 1701, which sought to curtail the group's military activities and thus linked the liberal peace project to broader regional security concerns, a large majority of Shi'a and a substantial minority of Lebanese of other confessions have come to see liberal peace actors as partial. ${ }^{43}$ Disengagement is also facilitated by access to symbolic and material resources that do not depend on the liberal peace actors' goodwill. In securing resources, Hezbollah can of course count on its alliance with Iran, but one must also note the efficacy of its organizational structure. "The key to this is [Hezbollah's own NGO] Jihad Al Bina, which was established to provide medical, financial and practical support to Hezbollah members and its mainly Shiite supporters." 44 Hezbollah has also deployed symbols that resonate with its supporters and clearly set it apart from the liberal peace actors. The party is not interested in liberal democracy, Western style; nor is it particularly keen on liberal approaches to the economy. ${ }^{45}$ Instead, its "social and political activities operate as an integrated and holistic policy network, disseminating the values of resistance while constructing a collective identity derived from the notion of hala al-islamiyya, or "Islamic sphere." "46

Local elites opposed to the liberal peace project might want to sidestep efforts at democracy promotion; often, they cannot ignore the pervasive presence and resources deployed by liberal peace actors. In such instances, local elites attempt to manipulate the liberal peace actors' discourses and strategies to their own advantage. I call this recuperation, the diversion of symbolic and financial resources intended for democracy promotion so as to undermine the project. The adoption of this strategy is facilitated by the paradox whereby liberal peace actors find themselves forced to contend with local elites opposed to their project because sustainable peace depends on their inclusion in government. In Sudan, al-Bashir has used benefits derived from CPA implementation, including the development of Sudan's oil sector, to bolster his popular legitimacy. According to World Bank estimates, the country's gross domestic product nearly tripled and oil turned Sudan's economy into one of the fastest-growing 
economies in Africa. By 2006, direct foreign investment had shot up to $\$ 2.3$ billion from $\$ 128$ million in 2000.47 World Bank officials consider that "Sudan has some of the sharpest economic policy makers on the continent, who have invested wisely in infrastructure, education and the country's agriculture industry." 48 Although the wealth is not equally shared, it has boosted the government's popularity, securing al-Bashir's reelection with a comfortable margin in April 2010. Al-Bashir's popularity has been further strengthened by his ability to place the blame for the breakup of the country as a result of the 9 January 2011 referendum on the independence of South Sudan squarely on liberal peace actors. That he has been successful can be partially explained by the suspicion among many Sudanese that Western powers were not really interested in democracy and that their ultimate goal was to break up the country to put their hands on its oil wealth. This suspicion was fed by the selectiveness of liberal peace actors' strategies and their willingness to reach compromises with the ruling NCP to safeguard the peace and remain in country at critical junctures. The suspicion extends beyond the circle of regime supporters to opposition leaders including al-Bashir's only serious competitor for the presidency in 2010, the SPLM's Yasir Arman. ${ }^{49}$ Thus, his popularity and his victory at the polls have provided al-Bashir with symbolic (even procedurally democratic) resources that he deploys to counter the liberal peace project.

Disengagement and recuperation are not exclusive of one another. The cases of Sudan and Lebanon make abundantly clear the extent to which both can be facilitated by the missteps of liberal peace actors, themselves a function of the inherent paradoxes that beset any peace- or statebuilding enterprise. The two cases also highlight the ability of local elites to adopt and adapt democratic norms (popular legitimacy) and practices (electoral victories) to their own ends.

\section{Bargaining Interactions and Postconflict Governance: Wither Democracy?}

In this article, I used the lens of democracy promotion to describe interactions between liberal peace actors and local elites opposed to the liberal peace project. Using evidence from Sudan and Lebanon, I documented the way in which liberal peace projects, rather than creating a state of exception, systematically provide opportunities for local elites to overcome the apparent asymmetry of power between them and liberal peace actors. I also identified two strategies of resistance to the promotion of democracy: disengagement and recuperation.

In postconflict settings, democracy promotion is a daunting task. Liberal peace actors hold democratic norms and practices important for the nonviolent management of conflicts; simultaneously, they are forced to make difficult compromises in terms of preferred strategies and local partners. Rather than evaluating postconflict governance in black or white terms, equating success 
with democracy and failure with hybridity, the pervasiveness of bargaining and the inevitability of mixed outcomes suggest the need for a different analytical frame. In this article, I argue that disengagement and recuperation are not mutually exclusive. But is one of them more likely to negatively affect the stability of transition from war to peace?

Sudan suggests that this might indeed be the case. As the transitional period mandated by the CPA came to an end in 2011 and as it became clear that Sudan would be divided, liberal peace actors lost leverage on the al-Bashir government. As had happened during the negotiations leading to the CPA, alBashir became frustrated as liberal peace actors failed to make good on the promises they made to ensure the peaceful holding of the January 2011 referendum. With little else to gain from bargaining, al-Bashir signaled his increasing disengagement by refusing to extend the UNMIS mandate. This was accompanied by mounting violence in Abyei and in the two border states of Blue Nile and South Kordofan.

If a dominant strategy of disengagement threatens peace, how does a dominant strategy of recuperation affect postconflict governance? Lebanon provides preliminary answers. Hezbollah did not simply disengage from the liberal peace project; it skillfully used the democratic opportunities afforded by elections to bolster its legitimacy. The party, which won the 2009 popular vote, though not the election, is now part of the governing majority. In the past year, Hezbollah has had to contend with the STL decision to indict four of its members in connection with the assassination of Hariri. While the party forcefully rejected the accusations and refused to cooperate with the tribunal, it has also had to carefully weigh its options. Following the release of the indictments, Hezbollah leader, Hassan Nasrallah, cast doubt on the legitimacy of the STL process. He presented "evidence" to the fact that tribunal officers were connected to organizations, including the Central Intelligence Agency, which wanted to get rid of the party for reasons having to do with the war on terror. Tellingly, however, he pledged to act responsibly and not to allow the issue to cause further sedition or civil war in Lebanon. One must recall that the crisis between Hezbollah and the Lebanese allies of the liberal peace actors had resulted in a violent flare-up in May 2008. If the core of democracy promotion is the lesson that conflicts can be managed peacefully, then the outward engagement of Hezbollah with democratic procedures may have contributed to moderating the party.

This probe requires further theoretical elaboration and empirical testing. However, preliminary conclusions suggest that any assessment of postconflict governance cannot be limited to an evaluation of the local actors' ability to spoil the process or the commitment of international actors to see it through. It must also take into account the myriad ways in which locals can evade, adapt, and subvert the process and their consequences on the quality of postconflict governance. 


\section{Notes}

Marie-Joëlle Zahar is associate professor of political science and research director of the Francophone Research Network on Peace Operations at the Université de Montréal.

1. Barry R. Posen, "The Security Dilemma and Ethnic Conflict," in Michael Brown, ed., Ethnic Conflict and International Security (Princeton: Princeton University Press, 1993), pp. 103-124; Jack Snyder and Robert Jervis, "Civil War and the Security Dilemma," in Barbara F. Walter and Jack Snyder, eds., Civil Wars, Insecurity, and Intervention (New York: Columbia University Press, 1999); William Rose, "The Security Dilemma and Ethnic Conflict: Some New Hypotheses," Security Studies 9, no. 4 (2000): 1-51.

2. Stephen M. Saideman and Marie-Joëlle Zahar, eds., Intra-state Conflict, Governments and Security: Dilemmas of Deterrence and Assurance (London: Routledge, 2008); Jean-Paul Azam and Alice Mesnard, "Civil War and the Social Contract," Public Choice 115 (2003): 455-475.

3. Roland Paris and Timothy D. Sisk, eds., The Dilemmas of Statebuilding: Confronting the Contradictions of Postwar Peace Operations (New York: Routledge, 2009).

4. Kimberly Zisk Marten, Enforcing the Peace: Learning from the Imperial Past (New York: Columbia University Press, 2004), p. 3.

5. Ibid., p. 5.

6. Stephen John Stedman, "Spoiler Problems in Peace Processes," International Security 22, no. 2 (Fall 1997): 5-53; Barbara F. Walter, "The Critical Barrier to Civil War Settlement," International Organization 51, no. 3 (Summer 1997): 335-364.

7. Arend Lijphart, "The Power Sharing Approach," in Joseph V. Montville, ed., Conflict and Peacemaking in Multiethnic Societies (Lexington, MA: Lexington Books, 1990); Timothy D. Sisk, Power Sharing and International Mediation in Ethnic Conflicts (Washington, DC: United States Institute of Peace Press, 1996).

8. Barbara F. Walter, "Does Conflict Beget Conflict? Explaining Recurring Civil War," Journal of Peace Research 41, no. 3 (2004): 371-388.

9. Mansoob Murshed, "Inequality, Indivisibility and Insecurity," in Stephen M. Saideman and Marie-Joëlle Zahar, eds., Intra-state Conflict, Governments and Security: Dilemmas of Deterrence and Assurance (London: Routledge, 2008), pp. 54-71.

10. Thomas Carothers, "Democracy Assistance: Political vs. Developmental?" Journal of Democracy 20, no. 1 (January 2009): 5-19. See also Krishna Kumar, ed., Postconflict Elections, Democratization, and International Assistance (Boulder: Lynne Rienner, 1998); Marina Ottaway, "Promoting Democracy After Conflict: The Difficult Choices," International Studies Perspectives 4 (2003): 314-322; Anna K. Jarstad and Timothy D. Sisk, eds., From War to Democracy: Dilemmas of Peacebuilding (Cambridge: Cambridge University Press, 2008); Peter Burnell, "From Evaluating Democracy Assistance to Appraising Democracy Promotion," Political Studies 56 (2008): 414-434.

11. Carothers, "Democracy Assistance," p. 5.

12. A. Hurwitz and G. Peake, Strengthening the Security-Development Nexus: Assessing International Policy and Practice Since the 1990s (New York: International Peace Academy, 2004), p. 9.

13. Oliver Richmond, "The Linkage Between Devious Objectives and Spoiling Behaviour in Peace Processes," in Edward Newman and Oliver Richmond, eds., Spoilers and Peace Processes: Conflict Settlement and Devious Objectives (Tokyo: United Nations University Press, 2006), pp. 59-77.

14. Roland Paris, At War's End: Building Peace After Civil Conflict (Cambridge: Cambridge University Press, 2004).

15. Shahrbanou Tadjbakhsh, ed., Rethinking Liberal Peace: Political and Economic Models, Limitations and Alternatives (London: Routledge, 2011). 
16. Anna K. Jarstad and Roberto Belloni, "Introducing Hybrid Peace Governance: Impact and Prospects of Liberal Peacebuilding," in this issue.

17. Michael Barnett and Christopher Zürcher, "The Peacebuilder's Contract: How External Statebuilding Reinforces Weak Statehood," in Roland Paris and Timothy D. Sisk, eds., The Dilemmas of Statebuilding: Confronting the Contradictions of Postwar Peace Operations (New York: Routledge, 2009), pp. 23-52.

18. Daniel Allen, "New Directions in the Study of Nation-building: Views Through the Lens of Path Dependence," International Studies Review 12 (2010): 413-429; Anna K. Jarstad and Timothy D. Sisk, eds., From War to Democracy: Dilemmas of Peacebuilding (Cambridge: Cambridge University Press, 2008); Marie-Joëlle Zahar, "Liberal Interventions, Illiberal Outcomes: The UN, Western Powers, and Lebanon," in Edward Newman, Oliver Richmond, and Roland Paris, eds., New Perspectives on the Liberal Peace (Tokyo: United Nations University Press, 2009), pp. 292-315.

19. Aron Griffiths and Catherine Barnes, Powers of Persuasion: Incentives, Sanctions, and Conditionality in Peacemaking (London: Conciliation Resources, 2008).

20. Didier Fassin and Mariella Pandolfi, eds., Contemporary States of Emergency (New York: Zone Books, 2010); Laurence McFalls, "Benevolent Dictatorship: The Formal Logic of Humanitarian Government," in Didier Fassin and Mariella Pandolfi, eds., Contemporary States of Emergency (New York: Zone Books, 2010); Mariella Pandolfi, "Contract of Mutual (In)Difference: Governance and the Humanitarian Apparatus in Contemporary Albania and Kosovo," Indiana Journal of Global Legal Studies 10, no. 1 (2003): 369-381.

21. North Atlantic Treaty Organization, "NATO's Role in Kosovo," 15 September 2011, www.nato.int/cps/en/natolive/topics_48818.htm.

22. Gerhard Knaus and Felix Martin, "Travails of the European Raj," Journal of Democracy 14, no. 3 (July 2003): 60-74.

23. J. K. Boyce, "Aid Conditionality as a Tool for Peacebuilding: Opportunities and Constraints," Development and Change 33, no. 5 (2002): 1025-1048; Diane Ethier, "Is Democracy Promotion Effective? Comparing Conditionality and Incentives," Democratization 10, no. 1 (2003): 99-121; Rory Keane, "The Partnership-Conditionality Binary in the Western Balkans: Promoting Local Ownership for Sustainable Democratic Transition," Cambridge Review of International Affairs 18, no. 2 (July 2005): 247-258.

24. James C. Scott, Weapons of the Weak (New Haven: Yale University Press, 1985).

25. Rosalind O'Hanlon, "Recovering the Subject: Subaltern Studies and Histories of Resistance in Colonial South Asia," Modern Asian Studies 22, no. 1 (1988): 189-224; Stefano Varese, "The Ethnopolitics of Indian Resistance in Latin America," Latin American Perspectives 23, no. 2, Ethnicity and Class in Latin America (Spring 1996): 58-71.

26. Local actors can muster equivalent military might and financial resources in instances where the lack of international political will prevents a strong military commitment to a given mission or where local actors can access transnational financial resources (mostly illicit) in spite of the presence of international actors.

27. Stephen Brown, "Foreign Aid and Democracy Promotion: Lessons from Africa," European Journal of Development Research 17, no. 2 (June 2005): 179-198; Carrie Manning and Rachel Hayman, "Fostering Stability or Democracy? Aid for Democracy Promotion in Post-conflict Countries," paper presented at the annual meeting of the International Studies Association, Toronto, Ontario, September 2009. Disentangling foreign development aid from democracy promotion programs is methodologically tricky.

28. As per the website of the UN Development Programme, individual contributions to the UN basket fund for elections are as follows: Italy, $\$ 2,785,515$; United Kingdom (Department for International Development), \$15,494,540; Norway, \$5,499,694; 
Denmark-Danida, \$7,772,107; Sweden (Swedish International Development Cooperation Agency), \$6,955,764; Spain, \$1,000,000; Japan, \$10,033,328; European Commission, \$18,824,250; the Netherlands, \$14,345,700; France, \$1,505,940; www.sd.undp.org /projects/dg16.htm.

29. Richard Downie, "Applying OECD/DAC Guidance on Statebuilding in Southern Sudan," in Megan Gleason et al., Statebuilding in Situations of Fragility and Conflict: Relevance for US Policies and Programs (Washington, DC: DAI, 2011), p. 18.

30. Jose Maria Aranaz, senior human rights officer, Human Rights Section, UN Mission in Sudan, interviewed by the author, Khartoum, 16 August 2010.

31. Ibid.

32. Comments by Jason Gluck, senior rule of law adviser in the United States Institute of Peace's Rule of Law Center of Innovation, at a workshop on donor-NGO relations in postconflict settings, Lebanese American University, Beirut, July 2011.

33. David Sharer and Francine Pickup, "Dilemmas for Aid Policy in Lebanon and the Occupied Palestinian Territories," Humanitarian Exchange Magazine 37 (March 2007): 4-6, www.odihpn.org/report.asp?id=2871.

34. Alex de Waal, "Dilemmas of Multiple Priorities and Multiple Instruments: The Darfur Crisis," in Aaron Griffiths and Catherine Barnes, eds., Powers of Persuasion: Incentives, Sanctions and Conditionality in Peacemaking Accord, issue 19 (London: Conciliation Resources, 2008), p. 57.

35. Marie-Joëlle Zahar, "A Journey of a Thousand Steps: State and Nation Building in South Sudan," Middle East Report 41, no. 259 (Summer 2011): 36-39.

36. Chandra Lekha Sriram and Marie-Joëlle Zahar, "The Perils of Power-sharing: Africa and Beyond," Africa Spectrum 44, no. 3 (2009): 11-39; Marie-Joëlle Zahar, "Power Sharing in Lebanon: Foreign Protectors, Domestic Peace, and Democratic Failure," in Philip Roeder and Donald Rothchild, eds., Sustainable Peace: Power and Democracy After Civil Wars (Ithaca: Cornell University Press, 2005), pp. 219-240.

37. Al-Baqir Mukhtar, director, Al-Khatim Adlan Centre for Enlightenment and Human Development, interviewed by the author, Khartoum, 28 July 2010.

38. Ibid.

39. Ahmed Abusin, director, Development Partners, interviewed by the author, Khartoum, 27 July 2010.

40. Comments by Samer Abdallah, general coordinator, Nahwa al-Muwatiniyya, at a workshop on donor-NGO relations in postconflict settings, Lebanese American University, Beirut, 22 July 2011.

41. Elias Muhanna, "Deconstructing the Popular Vote in Lebanon's Election," Mideast Monitor 4, no. 1 (July-August 2009), www.mideastmonitor.org/issues/0907 /0907_3.htm.

42. Roger Mac Ginty, "Reconstructing Post-war Lebanon: A Challenge to the Liberal Peace?" Conflict, Security and Development 7, no. 3 (2007): 464.

43. See Marie-Joëlle Zahar, "Liberal Interventions, Illiberal Outcomes: The UN, Western Powers, and Lebanon," in Edward Newman, Oliver Richmond, and Roland Paris, eds., New Perspectives on the Liberal Peace (Tokyo: United Nations University, 2009), pp. 292-315.

44. Mac Ginty, "Reconstructing Post-war Lebanon," p. 470.

45. Roger Mac Ginty and Christine Sylva Hamieh, "“Made in Lebanon': Local Participation and Local Development to Post-war Reconstruction," Civil Wars 12, nos. $1-$ 2 (2010): 47-64. See also Christine Sylva Hamieh and Roger Mac Ginty, "A Very Political Reconstruction: Governance and Reconstruction in Lebanon After the 2006 War," Disasters: The Journal of Disaster Studies, Policy and Management 33, no. 1 
(2009): 103-123. In their work, Mac Ginty and Hamieh disentangle the myriad ways in which, in spite of its opposition to the liberal peace project, Hezbollah will sometimes engage liberal peace actors and attempt to capture their programs to its own ends.

46. Mona Harb and Reinoud Leenders, "Know Thy Enemy: Hizbullah, 'Terrorism' and the Politics of Perception," Third World Quarterly 26, no. 1 (2005): 192.

47. Jeffrey Gettleman, "War in Sudan? Not Where the Oil Wealth Flows," New York Times, 24 October 2006, p. A1.

48. Jeffrey Gettleman, "Sudan's Growth Buoys a Leader Reviled Elsewhere," New York Times, 15 April 2010, p. A4.

49. Yasir Arman, SPLM presidential candidate and senior official, interviewed by the author, Khartoum, 28 July 2010. 